\title{
Perkembangan Karakter Siswa dalam Pembelajaran Matematika di Kelas Rendah Sekolah Dasar
}

\author{
Mufidah $^{1 凶}$ \\ Pendidikan Guru Sekolah Dasar, Universitas Tadulako, Indonesia(1) \\ DOI: $10.31004 /$ obsesi.v6i3.1696
}

\begin{abstract}
Abstrak
Penelitian ini berusaha mengungkapkan bagaimanakah perkembangan karakter siswa dalam pembelajaran matematika. Sehingga tujuan penelitian ini adalah mendeskripsikan perkembangan karakter siswa kelas rendah SD ditinjau dari pengetahuan, perasaan dan perbuatan moral mereka selama dan setelah mengikuti pelajaran matematika. Penelitian ini menggunakan jenis penelitian deskrpitif evaluatif dengan pendekatan metode penelitian gabungan antara metode penelitian kualitatif dan kuantitatif dengan desain penelitian evaluative. Hasil penelitian ini menunjukan bahwa karakter siswa kelas rendah di SDN 15 Palu mengalami perkembangan yang sangat baik. Hasil dari kajian penelitian ini adalah perlu upaya peningkatan kesiapan guru dalam mengajar, yakni: penguasaan materi pembelajaran matematika, penyiapan RPP Matematika berkarakter, dan kemampuan mengaitkan materi yang diajarkan dengan metode yang lebih variatif dan menarik di dalam pembelajaran matematika perlu diintensifkan karakter yang terintegrasi di dalamnya. Upaya pengelolaan kelas yang baik dan peningkatan penugasan dalam bentuk kelompok belajar dengan menggunakan metode yang lebih variatif dan menarik oleh guru juga perlu ditingkatkan.
\end{abstract}

Kata Kunci: perkembangan karakter; pembelajaran matematika; sekolah dasar.

\begin{abstract}
This study seeks to reveal the development of students' character in learning mathematics. Therefore the purpose of this study was to describe the character development of lower grade elementary school students in terms of their moral knowledge, feelings and actions during and after attending math lessons. This research uses descriptive evaluative research with a combined research method approach of qualitative and quantitative methods. The results indicate that the character of the students has developed very well. The results show that efforts are needed to increase teacher readiness in teaching, namely: mastery of mathematics learning materials, preparation of Characterized Mathematics lesson plans, and the ability to link the material taught with more varied and interesting methods. Good classroom management efforts and increasing assignments of study groups using more varied and interesting methods by teachers also need to be improved.
\end{abstract}

Keywords: character development; mathematics learning; primary school.

Copyright (c) 2021 Mufidah.

$\square$ Corresponding author:

Email Address : fida.mathc@gmail.com (Palu, Sulawesi Tengah, Indonesia)

Received 16 May 2021, Accepted 7 August 2021, Published 20 August 2021 


\section{PENDAHULUAN}

Karakter dalam diri peserta didik akan berpengaruh pada kehidupan mereka selanjutnya. Sehingga dalam hal ini harus dipahami bahwa kemampuan kognisi seseorang dapat membantu dirinya dalam meningkatkan kehidupan hanya seperlima dari seluruh struktur jiwa. Namun dalam pelaksanaannya, penyelenggara pendidikan saat ini masih banyak menitikberatkan pada transfer ilmu dan pengetahuan kepada peserta didik (Indrianto \& Sya' diyah, 2020). Sementara itu, afeksi memegang peranan yang cukup menentukan dalam hal tersebut (Pidarta, 2009). Muslich (2011) juga mengungkapkan, bahwa salah satu penyebab ketidakmampuan seseorang untuk berperilaku baik, walaupun secara kognitif ia mengetahuinya, yaitu karena ia tidak terlatih untuk melakukan kebajikan. Oleh karenanya, peserta didik membutuhkan lingkungan yang tidak hanya dapat meningkatkan kemampuan kognisinya tetapi juga meningkatkan kemampuan afeksinya.

Pendidikan karakter anak-anak SD usia 6-8 tahun masih menjadi permasalahan tersendiri yang belum dapat terselesaikan (Sabardila et al., 2021). Pendidikan karakter perlu diperkenalkan kepada anak sejak usia dini mengingat perlakuan yang diberikan kepada anak di usia dini akan terpateri kuat di dalam diri anak (Suyanto, 2012). Penanaman karakter harus dilakukan sejak anak usia dini, supaya karakter tersebut mengakar kuat pada diri anak hingga dewasa (Amini \& Mariyati, 2021). Sekolah Dasar merupakan tempat pendidikan awal yang baik bagi tidak hanya bagi peningkatan kemampuan kognisi tetapi juga bagi penanaman karakter anak dalam perkembangan dirinya. Hal ini dikarenakan pembinaan karakter yang termudah dilakukan adalah ketika anak-anak masih berusia dini dan duduk di bangku SD. Usia dini merupakan masa emas (golden age) dan juga periode kritis dalam tahap perkembangan manusia (Apriliyanti et al., 2021). Usia ini terbukti sangat menentukan kemampuan anak dalam mengembangkan potensinya. Dengan demikian adalah lebih mudah bila pendidikan karakter diajarkan pada usia ini, karena melekat di jiwa anak-anak hingga dewasa. Oleh karenanya pendidikan karakter harus dimulai sejak dini yakni dari jenjang pendidikan SD.

Dalam upaya pengembangan pendidikan karakter agar dapat berjalan dengan baik, maka diperlukan suatu perencanaan yang matang dalam pelaksanaannya (Sunarto \& Sagirani, 2014). Dengan demikian pembelajaran matematika selain harus meningkatkan perhatian kepada pembelajaran nilai-nilai juga harus secara lebih sistemik memperhatikan pola pengembangan karakter yang tepat. Untuk itu perlu diupayakan bagaimana memfungsikan matematika sekolah sebagai wahana untuk menumbuhkembangkan kecerdasan, ketrampilan, serta untuk membentuk karakter siswa secara lebih sistemik. Penelitian ini diharapkan dapat menjadi salah satu referensi yang baik dalam upaya pengembangan pendidikan karakter.

Penelitian karakter siswa berarti penelitian yang dilaksanakan terhadap aspek afeksi siswa. Pidarta (2009) memaparkan bahwa pada aspek afeksi terdapat 16 karakter yang dapat dijabarkan, yaitu : Kemauan, Sikap, Tanggung jawab, Akuntabilitas, Komitmen, Motivasi, Penghargaan, Penghormatan, Kesopanan, Persahabatan, Kasih sayang, Religius, Toleransi, Kerja sama, Kedermawanan dan Estetika. Karakter tersebut adalah karakter-karakter siswa yang perlu diteliti lebih lanjut perkembangannya dalam pembelajaran matematika. Adapun karakter siswa yang digunakan dalam penelitian ini lebih memfokuskan pada 5 karakter yang diambil dari 16 karakter tersebut, yaitu karakter kemauan, tanggung jawab, komitmen, motivasi, dan kerja sama. Karakter-karakter tersebut dipilih dengan pertimbangan bahwa karakter-karakter tersebut juga terintegrasi di dalam pembelajaran matematika namun selama ini belum ada penelitian yang secara khusus memantau perkembangan kelima karakter tersebut dalam pembelajaran matematika.

Pembentukan karakter harus dilakukan secara sistematis dan berkesinambungan dengan mengikutsertakan beberapa aspek, antara lain: pengetahuan, perasaan, kasih sayang, dan tindakan (Saihu \& Rohman, 2019). Lickona (2012) mengungkapkan bahwa komponenkomponen Pendidikan karakter yang baik di sekolah terdiri dari pengetahuan moral, 
perasaan moral dan tindakan moral. Olehnya perkembangan karakter yang dimaksud dalam penelitian ini adalah keseluruhan pola kelakuan dan kemampuan yang ada pada siswa sebagai hasil dari pembawaan dari lingkungan sosialnya yang berkembang di dalam pembelajaran matematika yang ditinjau dari pengetahuan moral, perasaan moral dan tindakan moral.

Dengan mengambil dasar-dasar pemikiran di atas perlu dilaksanakan penelitian terhadap perkembangan karakter untuk memonitoring perkembangan pendidikan karakter dan juga demi mengetahui hal - hal yang dapat menunjang kesuksesan perkembangan pendidikan karakter. Dalam hal ini peneliti memandang perlu untuk melakukan suatu penelitian yang berkaitan dengan perkembangan perilaku karakter dalam pembelajaran Matematika dengan judul "Perkembangan Karakter Siswa dalam Pembelajaran Matematika di Kelas 3 SD".

\section{METODOLOGI}

Dalam penelitian ini peneliti menggunakan jenis penelitian deskrpitif evaluatif dengan pendekatan metode penelitian gabungan antara metode penelitian kuantitatif dan kualitatif. Pada metode kualitatif instrumen utama dalam penelitian ini adalah peneliti sendiri. Peneliti sendiri sebagai instrumen utama untuk mendatangi secara langsung sumber data, mengiplementasikan data yang di kumpulkan dalam penelitian ini dalam bentuk deskripsi kata-kata yang didukung oleh angka-angka. Adapun data observasi, dokumentasi dan pedoman wawancara tertsruktur secara kuantitatif mendukung àtau melengkapi data instrument kualitatif tersebut. Pengecekan keabsahan data peneliti menggunakan kriteria kredibilitas, yakni prolonged engagement dan Persistent Observation. Teknik analisis data dalam penelitian ini adalah model Miles dan Huberman (1992) yang mencakup tiga tahapan yaitu reduksi data, penyajian data, dan pengambilan kesimpulan.

Tujuan penelitian ini adalah untuk mendeskripsikan perkembangan karakter siswa kelas 3 SD yang ditinjau dari pengetahuan, perasaan dan tindakan moral mereka selama dan setelah mengikuti pelajaran matematika. Berdasarkan tujuan penelitian tersebut, maka jenis penelitian ini adalah penelitian evaluatif. Menurut Pidarta (2008) penelitian bersifat evaluatif bila bertujuan menilai objek-objek yang akan diteliti. Objek-objek yang dinilai dalam penelitian ini adalah karakter-karakter siswa yang dapat dikembangkan dalam pembelajaran matematika.

Desain penelitian evaluatif dilaksanakan dengan: (1) Memotret fokus-fokus yang diinginkan; (2) Mengevaluasi fokus-fokus yang telah ditemukan dengan membandingkan pada standar atau konsep yang sudah baik yang ditulis pada bab kajian pustaka; (3) Memberi jalan keluar terhadap fokus-fokus yang belum terlaksana dengan baik. Subjek terdiri dari 29 orang siswa kelas III yang berasal dari SDN 15 Palu dan setelah melalui serangkaian proses pengumpulan data yang kemudian menjadi jenuh, subjek tersebut menjadi 7 orang. Ketujuh subjek tersebut kemudian diamati dalam waktu kurang lebih tiga bulan. Hal - hal yang diamati dari ketujuh subjek tersebut adalah perkembangan pengetahuan, perasaan dan perbuatan moral karakter para siswa tersebut selama 5 fase (F1,F2,F3,F4 dan F5) pertemuan di SDN 15 Palu.

Tabel 1. Daftar subjek penelitian yang mewakili 29 Siswa

\begin{tabular}{cc}
\hline SUBJEK & MEWAKILI \\
\hline S01 & 2 Siswa \\
S02 & 5 Siswa \\
S03 & 4 Siswa \\
S04 & 8 Siswa \\
S05 & 3 Siswa \\
S06 & 5 Siswa \\
S07 & 2 Siswa \\
\hline
\end{tabular}

HASIL DAN PEMBAHASAN 
Rentang usia dini pada sekolah dasar terdapat pada peserta didik di kelas 1-3. Pada usia tersebut seluruh aspek perkembangan kecerdasan seperti IQ, EQ dan SQ tumbuh berkembang sangat luar biasa (Sururuddin, 2018). Pada rentang usia itu, peserta didik mulai menunjukkan perilaku belajar konkrit, integratif dan hierarkis, sehingga dalam proses pembelajaran tematik tepat sekali diterapkan pendidikan karakter yang memadai (Wardani, 2012). Pada penelitian ini perkembangan karakter siswa kelas III SD dideskripsikan berdasarkan komponen-komponen Pendidikan karakter yang baik di sekolah Lickona (2012), yaitu :

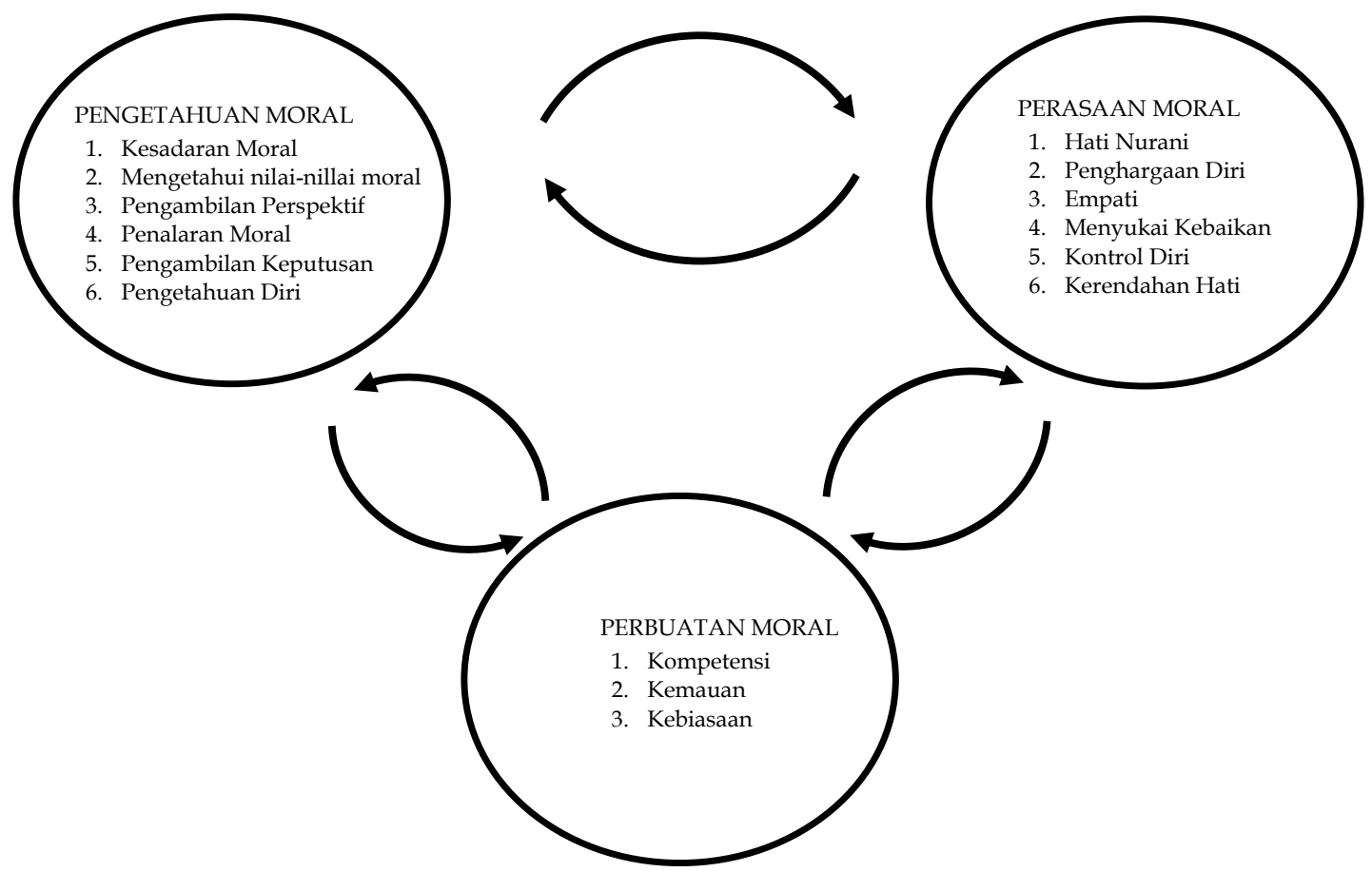

Gambar 1. Komponen Karakter yang Baik

Berikut ini dijelaskan hasil penelitian perkembangan karakter siswa dalam pembelajaran matematika di Kelas III SDN 15 Palu.

\section{Deskripsi Perkembangan Karakter Pengetahuan Moral Siswa}

Penelitian yang dilaksanakan pada pengetahuan moral siswa bertujuan untuk menggali data tentang bagaimana siswa mengetahui dan memahami karakter yang dia miliki yang merupakan pertemuan yang penting untuk diamati dan diteliti karena merupakan titik tolak pengukuran terhadap perkembangan karakter siswa. Tabel 2 dan Gambar 2 grafik di bawah ini mendeskripsikan perkembangan pengetahuan moral siswa.

Tabel 2. Perkembangan Moral Knowing

\begin{tabular}{clccccc}
\hline NO & KARAKTER & F1 & F2 & F3 & F4 & F5 \\
\hline 1 & Kemauan & 2,9 & 3,1 & 3,3 & 3,3 & 3,4 \\
2 & Tanggung Jawab & 2,7 & 3,0 & 3,3 & 3,4 & 3,4 \\
3 & Komitmen & 2,6 & 2,9 & 3,1 & 3,1 & 3,1 \\
4 & Motivasi & 2,7 & 2,9 & 3,3 & 3,4 & 3,4 \\
5 & Kerja Sama & 2,6 & 3,0 & 3,1 & 3,1 & 3,3 \\
\hline \multicolumn{2}{r}{ Rata - Rata } & 2,7 & 3,0 & 3,2 & 3,3 & 3,3 \\
\hline
\end{tabular}




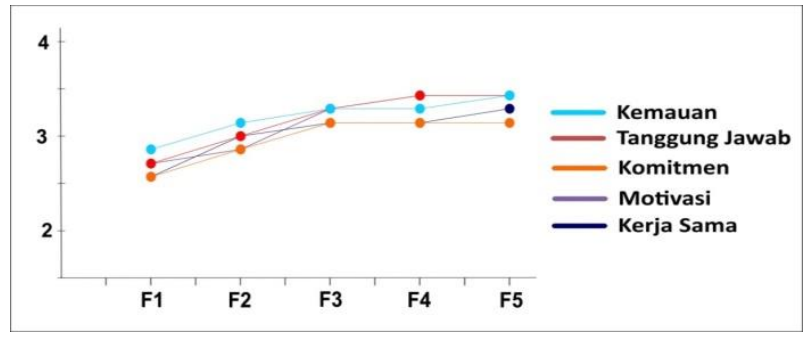

\section{Gambar 2. Grafik Perkembangan Moral Knowing}

Perkembangan karakter siswa dalam hal pengetahuan tentang moral siswa di Kelas III SDN 15 Palu secara umum diketahui sudah baik. Perkembangan pengetahuan karakter yang baik adalah bila memenuhi komponen-komponen pengetahuan karakter (Lickona, 2012). Hasil penelitian menunjukkan bahwa hampir seluruh siswa telah memenuhi komponenkomponen pengetahuan moral yang baik. Komponen-komponen yang dimaksud adalah kesadaran moral, pengetahuan tentang nilai-nilai moral, penentuan sudut pandang, logika moral, keberanian mengambil sikap, dan pengenalan diri. Hasil ini akan sangat mendukung dalam fase awal proses pembentukan karakter anak di usia dini dimana anak-anak didik diberi pengetahuan dan pemahaman akan nilai- nilai kebaikan yang universal (pengetahuan moral) sehingga pada akhirnya membentuk kepercayaan (Francisca \& Ajisuksmo, 2015).

\section{Kemauan}

Penelitian perkembangan pengetahuan siswa diadakan dengan melihat perkembangan pengetahuan kemauan para siswa berdasarkan komponen-komponen pengetahuan moral dari hasil wawancara. Bila melihat pemenuhan komponen-komponen tersebut pengetahuan kemauan para siswa telah berada pada tingkat yang baik. Kesadaran moral kemauan berkaitan dengan kemampuan siswa mengetahui atau memahami karakter kemauan telah dimiliki oleh hampir seluruh siswa. Kesadaran moral kemauan siswa dalam penelitian ini adalah kemampuan mereka dalam mengetahui bahwa dibutuhkan kemauan yang kuat untuk dapat mengikuti pelajaran dengan baik. Hal ini tergambar dari jawaban mereka yang dapat disimpulkan seragam ketika ditanya, 'Apakah kamu akan belajar dengan sungguh-sungguh kalau pelajarannya kamu suka?':

"Iya. Saya suka pelajarannya kalau asyik. Kalau pelajarannya asyik saya pasti tertarik untuk mempelajarinya. Karena pelajaran yang asyik selalu membuat saya penasaran. Kalau saya penasaran saya pasti akan mempelajarinya dengan sungguh-sungguh."

Dari jawaban ini juga dapat diketahui bahwa penerapan pembelajaran matematika yang menyenangkan akan turut memberikan andil dalam peningkatan pengetahuan moral siswa. Sebagaimana Ansori (2021) menyatakan untuk memberikan pengetahuan tentang moral, metodenya mesti menyesuaikan dengan perkembangan anak yaitu dengan cara belajar sambil bermain karena bermain bagi anak memberikan pandangan belajar tetapi menyenangkan sekaligus juga menghibur. Hal ini kemudian yang menumbuhkan kemauan siswa yang kuat untuk belajar matematika, sebaliknya para siswa juga mengetahui apa yang membuat mereka tidak bisa belajar matematika dengan baik adalah karena mereka tidak memiliki kemauan yang kuat untuk belajar matematika. Para siswa yang tidak memiliki kesadaran terhadap kemauannya dikarenakan mereka tidak memahami apa itu kemauan dan atau mereka tidak mengerti dengan apa yang sebenarnya mereka mau. Sehingga mereka tidak memiliki pertimbangan pikir yang baik untuk mengarahkan mereka pencapaian prestasi di bidang matematika atau yang lainnya.

Kemauan baik adalah karakter yang bersumber dari dalam diri individu (Firdaus et al., 2020). Pengetahuan tentang nilai-nilai moral pada karakter kemauan berkaitan dengan pengetahuan diri para siswa terhadap nilai-nilai kemauan itu sendiri. Hasil penelitian menunjukkan bahwa sebagian besar siswa telah memiliki tingkat pengetahuan nilai moral 
kemauan yang baik. Pengetahuan nilai moral kemauan para siswa ditinjau pengetahuan tentang pentingnya memperhatikan guru yang sedang menjelaskan. Bila para siswa memiliki pemahaman bahwa matematika itu menyenangkan atau penting atau bahkan matematika itu pelajaran yang sulit, maka secara sadar mereka mengetahui bahwa penting untuk mau memperhatikan guru. Sebagaimana jawaban seluruh siswa yang senada, "Iya Bu, kita harus memperhatikan guru yang sedang menerangkan". Meskipun begitu mereka memiliki alasan berbeda kenapa mereka harus memperhatikan guru: Subjek S01, S05, S06 dan S07 beralasan; "Kalau tidak diperhatikan nanti dimarahi guru". Sementara subjek S02,S03 dan S04 beralasan;

"Kalau tidak diperhatikan nanti tidak mengerti karena matematika itu sulit"

\section{Tanggung jawab}

Secara keseluruhan para siswa sudah dapat memenuhi komponen-komponen penting pengetahuan tanggung jawab pada tingkatan yang baik. Hal ini dimungkinkan juga karena karakter tanggung jawab masuk ke dalam salah satu dari nilai-nilai yang terkandung dalam pendidikan budaya dan karakter bangsa yang terintegrasi secara menyeluruh ke dalam hampir seluruh Kompetensi Dasar. Komponen kesadaran akan tanggung jawab telah dipenuhi oleh hampir seluruh siswa dengan mengetahui pentingnya mentaati tugas atau kewajiban yang diberikan. Sebagaimana jawaban mereka yang senada ketika ditanyakan, apakah tugas yang diberikan harus dilaksanakan dengan penuh ketaatan?; "Iya bu, karena kalau tidak dikerjakan nanti ditegur guru."

Kesadaran pentingnya tugas atau tanggung jawab semakin menguat seiring dengan penugasan dalam bentuk kelompok peer teaching. Pada prinsipnya peer teaching menggunakan peserta didik untuk mengajar atau melatih pesera didik lainnya. Teknik pembelajaran ini masuk menggunakan metode role-play atau bermain peran. Menurut Irwansyah (2012) teknik bermain peran berarti memberi peran baru kepada peserta didik untuk menumbuhkan konteks imajinatif yang bermuara pada pengembangan dimensi kognitif (superior cognitive abilities). Masih dalam Irwansyah (2012) menurut Longaretty, dkk., dari beberapa nilai lebih yang didapat dari peer teaching salah satu diantaranya adalah meningkatkan tanggung jawab dan kemandirian belajar. Para siswa mengetahui bahwa tugas tersebut diberikan oleh guru dan harus dilaksanakan dengan penuh ketaatan yang merupakan bentuk dari pengetahuan nilai tanggung jawab mereka. Terlihat dari jawaban salah satu subjek (S03) yang turut diamini oleh siswa lain ketika ditanya alasan mengapa tugas atau kewajiban tersebut penting;

"Iyalah bu... Tugas yang diberikan guru kan bisa buat kita tambah mengerti dan tambah mahir. Jadi, pas ujian kita bisa menjawab soalnya karena sudah mahir, terus kita sekarang jadi tahu (materi) ini bisa dipakai buat apa nanti."

Siswa yang mengajarkan mengetahui bahwa tugas tersebut penting, karena ia berperan sebagai guru yang harus membuat teman-temannya dapat mengerti dan mengerjakan soal yang diberikan Teman yang diajarkan pun memahami bahwa ia harus bisa berperan dengan baik sebagai siswa dengan benar-benar berusaha untuk mengerti dan bisa menyelesaikan soal yang diberikan karena jika tidak seluruh anggota akan mendapatkan konsekwensinya. Pemahaman tersebut merupakan suatu bentuk penentuan sikap yang baik. Karena mampu menentukan sudut pandang yang baik terhadap tugas tersebut. Kepedulian siswa terhadap lingkungan sosial sekitarnya yang ditunjukan dengan kepedulian untuk mengajar temannya yang tidak mengerti dan kepedulian untuk mendengarkan temannya yang mengajar karena menyadari konsekwensi yang akan diterima bersama merupakan suatu bentuk pengetahuan logika tanggung jawab yang baik. Senada dengan hal tersebut (Irwansyah, 2012) mengungkapkan bahwa faktor yang mempengaruhi pengembangan karakter siswa adalah faktor keluarga, faktor lingkungan pendidikan dan faktor lingkungan masyarakat. 
Untuk meningkatkan pengetahuan tanggung jawab siswa, dibutuhkan informasi ataupun instruksi yang jelas mengenai tanggung jawab oleh guru di awal pembelajaran. Dalam hal ini Juwita (2019) mengungkapkan ada beberapa cara menumbuhkan sikap tanggung jawab dalam diri peserta didik yaitu, memberikan tugas, membiarkan anak mengambil keputusan sendiri, memberikan kepercayaan kepada peserta didik, memberi contoh dan menjadi teladan bagi peserta didik. dalam mengintegrasikan tanggung jawab dalam pelajaran hendaknya guru harus mampu pula mengaitkan materi dengan tanggung jawab. Ketika sedang mengaitkannya guru dapat bertukar pendapat tentang apa yang dimaksud dengan 'bertanggung jawab', seperti "Kita selalu menepati janji" "Kita selalu melakukan yang terbaik" "Kita dapat diandalkan", mereka dapat menuliskannya dalam bentuk kartu-kartu dan para siswa dapat menempelkannya di dinding kelas mereka. Selain itu slogan ataupun moto-moto yang berkaitan dengan tanggung jawab dapat di tempel di ruang kelas. Hal ini dapat merangsang perkembangan pengetahuan tanggung jawab siswa karena mereka turut dilibatkan dalam memahami dan memberi definisi tanggung jawab itu menggunakan imajinasi mereka.

\section{Komitmen}

Perkembangan pengetahuan komitmen siswa ditunjukan dengan telah terbentuknya pengetahuan mereka tentang pentingnya berpegang teguh dan fokus kepada keputusan yang diambil yang merupakan perwujudan dari kesadaran komitmen yang menyeluruh. Keputusan yang diambil dalam hal ini adalah keputusan untuk mengikuti pelajaran matematika ataupun pelajaran lainnya. Berpegang teguh dan fokus kepada keputusan yang diambil adalah dengan berusaha memusatkan segala daya dan energi mereka untuk mengikuti proses pembelajaran matematika, termasuk dalam mengerjakan tugas - tugas yang diberikan oleh gurunya. Dengan demikian kesadaran komitmen adalah ketika para siswa berkomitmen untuk terus mengikuti dan melakukan yang terbaik dalam mempelajari matematika.

Peningkatan perkembangan pengetahuan tanggung jawab juga didukung dengan pengetahuan terhadap nilai-nilai komitmen yang terjabarkan oleh pengetahuan para siswa melalui pentingnya penyelesaian tugas atau kewajiban tepat pada waktunya. Sebagaimana jawaban mereka:

"Tugas yang dikasih guru sudah pasti harus dikumpul sesuai dengan batas waktu yang guru minta. Kalau tidak nanti Bu Guru kecewa. Biasanya tidak mau menerima pekerjaan kalau telat menyetornya. Nanti kita tidak dapat nilai."

Penyelesaian tugas atau kewajiban tepat pada waktunya bukanlah sesuatu yang bisa dinegoisasi. Para siswa selayaknya memahami hal ini sebagai kewajiban yang mengikat yang harus mereka penuhi sebagai bentuk komitmen mereka untuk dapat menguasai atau lebih baik lagi dalam suatu pelajaran. Penentuan sudut pandang komitmen yang baik diketahui dari pemahaman mereka bahwa tugas atau kewajiban yang tidak diselesaikan dengan baik akan menimbulkan kerugian bagi diri sendiri dan orang lain. Para siswa mengetahui seperti ketika tugas yang diberikan tidak diselesaikan dengan baik akan menyebabkan nilai mereka rendah. Pemahaman tersebut menunjukkan perkembangan logika komitmen yang dimiliki sebagian besar siswa berada pada tingkatan yang baik yang mengindikasikan keberanian untuk menentukan sikap berkomitmen semakin terbentuk, meskipun masih ada sebagian kecil saja yang masih melakukan tindakan mencontek. Pengakuan terhadap pengetahuan berkomitmen tersebut kemudian mengembangkan pengakuan terhadap kemampuan diri mereka untuk berkomitmen.

\section{Motivasi}

Pengetahuan Motivasi siswa telah menunjukkan tingkatan yang baik. Para siswa secara keseluruhan mengetahui bahwa setiap masalah memiliki pemecahannya yang 
merupakan bentuk dari kesadaran motivasi yang baik. Kesadaran motivasi ini berkembang seiring dengan semakin banyaknya masalah yang dihadapi. Pembelajaran matematika sendiri sering mempertemukan para siswa dengan soal-soal dengan tingkat kesulitan yang berbedabeda. Ketika mereka telah menguasai satu metode penyelesaian soal, kemudian mereka diperhadapkan lagi dengan soal dengan tingkatan kesukaran lebih dari sebelumnya. Kesadaran itu muncul ketika setiap kali mereka menemui kesulitan dalam pengerjaan soal, sesulit apapun soal tersebut pasti ada jawabannya. Sebagaimana tergambar dalam jawaban mereka yang senada ketika ditanya, 'Apakah menurutmu soal-soal yang susah memiliki jawaban?;

"Iya bu, pasti ada. Karena bu guru bilang ada jawabannya dan ada teman-teman yang bisa menemukan jawabannya."

Kesadaran motivasi tersebut lah yang menjadikan mereka mengetahui bahwa dibutuhkan ketekunan untuk dapat menyelesaikan suatu masalah yang merupakan perwujudan dari perkembangan pengetahuan terhadap nilai motivasi yang baik dari para siswa. Para siswa yang telah memiliki pengetahuan nilai motivasi tersebut kemudian mengetahui dengan sendirinya bahwa penting untuk tidak gampang menyerah terhadap segala sesuatunya yang merupakan penentuan sudut pandang yang baik dari para siswa.

\section{Kerja Sama}

Pengetahuan kerjasama siswa telah berkembang dengan baik. Para siswa memiliki kesadaran kerja sama yang baik dengan telah mengetahui tentang pentingnya saling mendukung dan saling mengandalkan satu sama lainnya. Seringnya penugasan dalam bentuk kelompok, terlebih dengan metode peer teaching terbukti efektif dalam meningkatkan kesadaran kerja sama para siswa.

Dalam kerja kelompok setiap siswa dituntut untuk dapat melaksanakan tugasnya masing-masing, tugas-tugas tersebut saling berkaitan dan saling bergantungan satu sama lainnya. Hal tergambar melalui jawaban;

"Kalau kerja kelompok itu harus kompak. Semuanya boleh memberi pendapat, nanti kita pilih ide yang bagus dari pendapat teman-teman. Terus kita bagi tugas dan tiap orang harus melaksanakan tugasnya."

Jika ada satu saja siswa yang tidak melaksanakan tugasnya sebagaimana mestinya, maka pelaksanaan dan penyelesaian tugas kelompok tidak akan maksimal. Pengetahuan nilainilai kerja sama pun semakin berkembang dengan baik. Hal ini dapat dilihat dari pengetahuan mereka tentang pentingnya kebersamaan demi mencapai tujuan yang sama. Tugas kelompok dengan metode tutor sebaya memberikan konstribusi cukup besar dalam perkembangan pengetahuan kerja sama siswa. Longaretti (2002) memaparkan beberapa kelebihan metode tutor sebaya, di antaranya adalah meningkatkan interaktif sosial dalam pembelajaran, mengembangkan keterampilan bekerja dalam kelompok dan membangun semangat kerja sama. Para siswa semakin mengetahui bahwa dibutuhkan suatu kesepahaman yang sama bila ingin mencapai tujuan yang sama dengan baik yang merupakan perwujudan penentuan sudut pandang yang baik. Dengan mau menghargai pendapat orang lain perkembangan logika kerja sama, keberanian untuk bekerja sama dengan baik dan pemahaman terhadap motivasi diri untuk terus berkembang semakin meningkat.

\section{Deskripsi Perkembangan Karakter Perasaan Moral Siswa}

Penelitian yang dilaksanakan pada pengetahuan moral siswa bertujuan untuk menggali data tentang bagaimana siswa merasakan tentang karakter yang dia miliki yang merupakan pertemuan ketiga yang penting untuk diamati terhadap perkembangan karakter siswa. Gambar 3. grafik di bawah ini mendeskripsikan perkembangan perasaan karakter siswa. 
Tabel 3. Perkembangan Perasaan Moral

\begin{tabular}{clccccc}
\hline NO & KARAKTER & F1 & F2 & F3 & F4 & F5 \\
\hline 1 & Kemauan & 2,3 & 2,9 & 3,1 & 2,9 & 3,0 \\
2 & Tanggung Jawab & 2,4 & 3,0 & 3,1 & 3,1 & 3,1 \\
3 & Komitmen & 2,3 & 2,6 & 2,9 & 2,7 & 2,9 \\
4 & Motivasi & 2,0 & 2,7 & 3,0 & 3,0 & 3,1 \\
5 & Kerja Sama & 2,0 & 2,3 & 2,6 & 2,7 & 3,0 \\
\hline \multicolumn{2}{r}{ Rata - Rata } & 2,2 & 2,7 & 2,9 & 2,9 & 3,0 \\
\hline
\end{tabular}

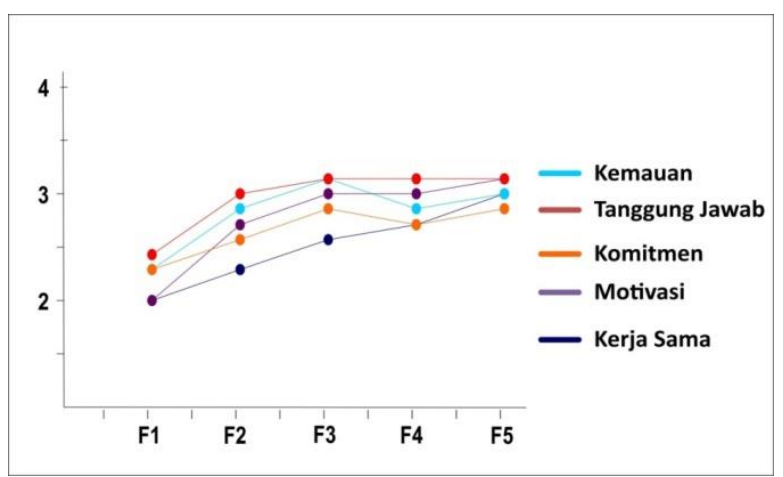

\section{Gambar 3. Perkembangan Perasaan Moral}

Perasaan moral berkaitan dengan membangun kecintaan berperilaku baik pada anak yang akan menjadi sumber energi anak untuk berperilaku baik. Perkembangan karakter siswa dalam hal perasaan moral karakter siswa di Kelas III SDN 15 Palu secara umum sudah baik. Komponen-komponen perasaan karakter yang hampir seluruh siswa telah penuhi adalah nurani, percaya diri , merasakan penderitaan orang lain, mencintai kebaikan, mampu mengontrol diri dan kerendahan hati. Upaya untuk menumbuhkan Perasaan Moral pada siswa dengan cara membangkitkan kesadaran nurani akan pentingnya komitmen melaksanakan nilai-nilai moral (Ansori, 2021).

\section{Kemauan}

Secara keseluruhan perasaan kemauan para siswa telah berkembang dengan baik. Sebagaimana definisi kemauan yang dipaparkan oleh Ahmad (2013) selain berdasar kepada pertimbangan pikir, pertimbangan perasaan beserta seluruh pribadi seseorang juga menjadi salah satu hal penting yang untuk memberikan dorongan yang menimbulkan kegiatan yang terarah pada pencapaian tujuan yang berhubungan dengan kebutuhan hidup pribadi seseorang. Pertimbangan perasaan menjadi suatu hal yang penting karena orang yang memiliki karakter yang baik tidak bertindak hanya berdasarkan pengetahuan yang dimilikinya tetapi juga karena keinginannya untuk berbuat baik yang bersumber dari kecintaan untuk berbuat baik. Muslich (2011) menyatakan, setelah anak memiliki pengetahuan, orang tua hendaknya dapat menumbuhkan rasa atau keinginan anak untuk berbuat baik. Piaget dalam Muslich (2011) juga menuturkan bahwa aspek kecintaan inilah sumber energi yang secara efektif membuat seseorang mempunyai karakter yang konsisten antara pengetahuan dan tindakannya.

Bila melihat pemenuhan komponen-komponen tersebut perasaan kemauan para siswa telah berada pada tingkat yang baik. Perasaan senang dalam menerima pelajaran maupun tugas yang diberikan merupaksan penggambaran wujud hati nurani yang memiliki kemauan yang baik. Ketika nurani seseorang memiliki atau tidak memiliki kemauan atas sesuatu akan terefleksikan langsung melalui roman muka dan tingkah lakunya yang merupakan ekspresi murni kejujuran. Perasaan senang terhadap matematika muncul bila hati nurani yang tergerak untuk mau atau senang terhadap matematika memunculkan dan membentuk komponen 
pelengkap perasaan kemauan lainnya. Perasaan senang dalam menerima pelajaran matematika Merasakan pentingnya memperhatikan guru yang sedang mengajar adalah kemampuan mengendalikan diri yang baik. Merasakan dibutuhkan ketelitian dalam mengerjakan tugas matematika merupakan perwujudan dari nilai rasionalitas para siswa. Sebagaimana Bishop dalam Kistanti (2019) mengungkapkan salah satu nilai yang dapat berkembang dalam pelajaran matematika ialah nilai matematika, yaitu nilai-nilai yang terkait dengan rasionalisme/objektifitas, control/kemajuan, dan keterbukaan. Para siswa yang memiliki pemikiran rasional dan objektif menunjukan adanya perkembangan perasaan karakter kemauan siswa.

\section{Tanggung Jawab}

Kemampuan para siswa dalam merasakan bahwa setiap tugas atau kewajiban itu penting siapapun yang memberikannya, merasakan takut atau tidak ingin mengecewakan orang lain membuat mereka mampu merasakan pentingnya untuk menaati segala tugas atau kewajiban merupakan perasaan yang bersumber dari hati nurani mereka, dan terhadap kebaikan ataupun keburukan yang dilakukan mereka mampu merasakan bahwa setiap perbuatan tersebut dapat memberikan dampak baik atau buruk kepada diri sendiri maupun orang lain yang harus dipertanggungjawabkan yang merupakan suatu bukti kecintaan mereka terhadap kebaikan sehingga mereka pun mampu merasa peduli terhadap keadaan lingkungan sekitarnya. Peduli pada lingkungan sekitar sebagai bentuk tanggung jawab adalah perwujudan perkembangan karakter yang baik karena anak-anak tersebut sudah mulai memiliki pengendalian diri atau emosi mereka dengan baik. Anak - anak yang bermasalah dalam kecerdasan emosinya akan mengalami kesulitan belajar, bergaul tidak dapat mengontrol emosinya (Sinaga, 2018). Kemampuan mereka dalam bertanggung jawab dikarenakan dapat mengendalikan emosinya dengan baik akan berdampak positif pada proses pembelajaran.

\section{Komitmen}

Kemampuan para siswa dalam merasakan bahwa segala sesuatunya akan dapat diselesaikan dengan baik bila terus berfokus untuk menyelesaikannya bersumber dari hati nurani mereka, sehingga mereka mampu merasakan bahwa tugas atau kewajiban yang tidak terselesaikan akan menimbulkan kerugian tidak hanya bagi diri sendiri tetapi juga bagi orang lain. Perasaan empati tersebut membuat para siswa semakin merasa mampu untuk berkomitmen kepada diri sendiri untuk selalu menyelesaikan tugas atau kewajiban dengan baik agar tidak merugikan orang lain. Para siswa pun memiliki kecintaan untuk berkomitmen dan berusaha untuk dapat mengendalikan sifat malas dan sifat lainnya yang bisa melunturkan komitmen mereka dan mereka pun selalu merasa butuh koreksi bila tidak mampu berkomitmen dengan baik yang menunjukkan kerendahan hati mereka.

\section{Motivasi}

Pada perkembangannya ketika saling mengajarkan (peer teaching) para siswa semakin mampu merasakan bahwa setiap masalah matematika memiliki penyelesaiannya yang merupakan perasaan yang muncul dari hati nurani mereka dan untuk menyelesaikan permasalahan tersebut mereka merasakan perlu meningkatkan ketekunan. Sebagaimana yang ditunjukan oleh teman - teman yang mengajar mereka, teman - teman mereka tersebut tidak gampang menyerah terhadap kekurang pahaman temanya yang lain karena mereka termotivasi untuk membantu teman mereka yang merupakan bentuk perasaan empati yang mengembangkan motivasi tersebut. Ketika proses pembelajaran metode peer teaching berakhir, para siswa pun semakin termotivasi untuk mau belajar yang menunjukkan keinginan besar untuk mengembangkan perasaan motivasi mereka, mereka merasa optimis bisa menyelesaikan soal yang diberikan bila mau lebih tekun mempelajari matematika . 


\section{Kerja Sama}

Perasaan membutuhkan kebersamaan untuk menjalin kerja sama yang baik bersumber dari nurani para siswa. Para siswa mampu berempati membantu teman yang kurang begitu pandai dalam bidang matematika dengan membangun kerja sama yang baik dalam pola saling mengajarkan (peer teaching). Para siswa yang pandai tidak sombong dan mau membantu dengan ikhlas bekerja sama untuk memahamkan temannya. Mereka bersedia saling mendengarkan pendapat satu sama lainnya yang menjadikan terbentuknya perasaan kesepahaman yang sama, sehingga merasa bisa bekerja sama dengan baik demi mencapai tujuan yang sama .

\section{Perkembangan karakter perbuatan moral siswa}

Penelitian yang dilaksanakan pada perbuatan moral siswa bertujuan untuk menggali data tentang bagaimana siswa berbuat atau bertindak berdasarkan pengetahuan dan perasaan moral yang para siswa miliki yang merupakan pertemuan ketiga yang penting untuk diamati karena menunjukkan perkembangan karakter siswa secara langsung. Tabel 4 dan Gambar 4 grafik di bawah ini mendeskripsikan perkembangan perilaku karakter siswa yang dapat diperoleh dari rata-rata tabel rekapitulasi hasil penelitian Perbuatan Moral yang dapat dilihat pada lampiran 5.

Tabel 4. Perkembangan Perbuatan Moral

\begin{tabular}{clccccc}
\hline NO & KARAKTER & F1 & F2 & F3 & F4 & F5 \\
\hline 1 & Kemauan & 1,9 & 2,7 & 3,0 & 2,9 & 3,0 \\
2 & Tanggung Jawab & 2,4 & 3,1 & 3,1 & 3,0 & 3,1 \\
3 & Komitmen & 2,3 & 2,9 & 3,0 & 3,0 & 3,0 \\
4 & Motivasi & 2,0 & 2,6 & 2,9 & 2,9 & 3,0 \\
5 & Kerja Sama & 2,6 & 2,7 & 2,9 & 3,0 & 3,3 \\
\hline \multicolumn{2}{r}{ Rata - Rata } & 2,2 & 2,8 & 3,0 & 2,9 & 3,1 \\
\hline
\end{tabular}

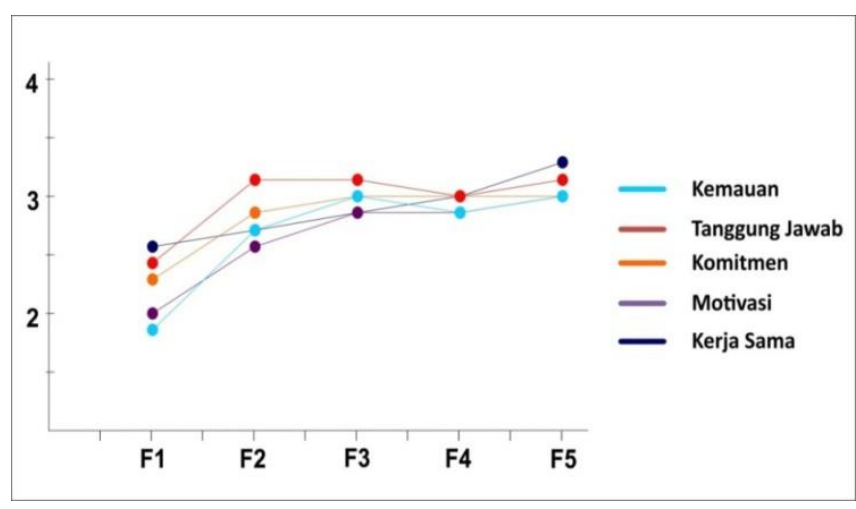

Gambar 4. Grafik Perkembangan Perbuatan Moral

\section{Kemauan}

Perkembangan perbuatan kemauan siswa sudah semakin baik yang ditunjukan dengan sikap antusias ataupun ketertarikan dalam mengikuti pelajaran dengan sudah lebih memperhatikan guru yang sedang menjelaskan, semakin seringnya mengajukan pertanyaan dan mereka terlihat lebih siap dalam menerima pelajaran matematika. Kesemuanya itu menunjukkan kekuatan keinginan mereka untuk mau belajar matematika semakin kuat. Setelah membentuk pemahaman dan sikap, maka dengan penuh kesadaran anak-anak akan bertindak dengan nilai-nilai kebaikan yang dianut sebagai ekspresi martabat dan harga diri (Francisca \& Ajisuksmo, 2015). Peningkatan kompetensi kemauan mereka ditunjukan dengan sudah semakin telitinya mereka dalam mengerjakan soal atau tugas yang diberikan oleh guru. Dari segi pembiasaan para siswa semakin terlihat sering mengerjakan soal matematika 
dengan penuh antusias mencari tahu cara menemukan jawaban yang tepat dan tidak segansegan lagi bertanya kepada guru ataupun teman bila menemukan kendala dalam pengerjaan.

\section{Tanggung Jawab}

Perkembangan kebiasaan tanggung jawab siswa terlihat semakin baik yang ditunjukan dengan kesungguhan mereka dalam menyelesaikan setiap tugas yang diberikan oleh guru dengan sangat baik. Kompetensi tanggung jawab yang dapat dilihat memiliki perkembangan adalah usaha koreksi yang mereka lakukan tiap kali menemui kesalahan dalam pengerjaan soal dan juga ketika diberikan tanggung jawab ketika berada pada kelompok peer teaching. Keinginan untuk bertanggung jawab pun terlihat meningkat dari sikap mereka yang berusaha menaati peraturan ataupun perintah yang diberikan baik oleh guru atau teman yang mengajar di kelompok tersebut. Penguatan - penguatan verbal berupa kata - kata pujian maupun non verbal berupa isyarat, seperti acungan jempol, senyuman, dan pemberian hadiah akan membantu meningkatkan tanggung jawab anak. Hal ini senada dengan hasil penelitian Amini \& Mariyati (2021) yang menemukan bahwa pemberian penguatan dalam bentuk pujian dan pemberian hadiah dapat meningkatkan karakter anak khususnya dalam perilaku bertanggung jawab.

\section{Komitmen}

Aktivitas pembelajaran kelompok, meningkatkan perkembangan keinginan untuk berkomitmen para siswa terlihat dari mereka yang berusaha keras bahu- membahu saling membantu temannya untuk memahamkan pelajaran dan memecahkan soal yang diberikan guru. Kompetensi komitmen para siswa semakin terlihat sudah lebih baik lagi ketika mereka menunjukkan sikap selalu menepati janji kepada guru kepada siapapun. Keinginan berkomitmen merekapun sudah semakin baik yang ditunjukan dengan komitmen mereka untuk mengerjakan semua tugas kelas dengan sungguh-sungguh. Kebiasaan mencontek mereka pun sudah semakin berkurang dan bahkan hampir tidak lagi terlaksana yang juga menunjukkan kesungguhan mereka untuk berkomitmen.

\section{Motivasi}

Keinginan motivasi para siswa telah berkembang dengan sangat baik pula, mereka semakin bersemangat mengerjakan soal-soal matematika, mereka tidak gampang menyerah dalam mencari jawaban yang juga menunjukkan kompetensi untuk menjadi tekun juga semakin baik dan mereka semakin terbiasa berpikiran positif dan optimis terhadap segala sesuatunya. Namun untuk memaksimalkan perbuatan motivasi siswa, maka sudah semestinya guru berperan aktif mengambil bagian di dalamnya. Kurang adanya perhatian dari beberapa guru dan peserta didik dapat menjadi penghambat dalam pengembangan karakter peserta didik (Pertama et al., 2017). Guru harus dapat menganalisa pendekatan motivasi apa yang bisa digunakan untuk mengembangkan perbuatan motivasi siswa.

\section{Kerja Sama}

Para siswa telah memiliki kebiasaan kerja sama yang baik. Bila dibandingkan dengan Perbuatan Moral yang lain, dapat terlihat jelas perkembangan perbuatan kerja sama lebih melampaui karakter-karakter lainnya. Para siswa di Kelas III ini sangat aktif dalam berbagai kegiatan ataupun dalam membuat kegiatan-kegiatan yang dilaksanakan secara kelompok. Hal ini dapat dilihat dari berbagai macam prakarya ataupun dokumentasi kegiatan kelas yang telah mereka laksanakan dan juga dari Aktivitas-Aktivitas pembelajarn yang sedang mereka laksanakan. Para siswa melaksanakan serangkaian kegiatan kelompok secara terstruktur; pembagian tugas dan perencanaan pencapaian target kelompok sangat jelas. Dari apa yang teramati, terlihat jelas bahwa guru yang bersangkutan menerapkan pembelajaran dengan metode cooperative learning. Sebagaimana menurut Johnson \& Johnson (dalam (Lie, 2008), belajar kooperatif didefinisikan sebagai sistem kerja atau belajar kelompok tersetruktur, dalam 
struktur ini, ada lima unsur pokok yang menyusunnya, yaitu saling ketergantungan positif, tanggung jawab individual, interaksi personal, keahlian bekerja sama, dan proses kelompok.

\section{Implikasi Penelitian Perkembangan Karakter}

Permasalahan pendidikan karakter yang selama ini ada di sekolah perlu segera dikaji dan dicari altenatif-alternatif solusinya serta perlu dikembangkannya secara lebih operasional sehingga mudah diimplementasikan (Wati, 2015). Penelitian asesmen perkembangan karakter ini meninjau pola perkembangan pengetahuan karakter dan perasaan karakter dan Perbuatan Moral para siswa. Dengan melihat seluruh perkembangan karakter di atas ditemukan bahwa: 1) Guru masih perlu mempersiapkan materi pembelajarannya dengan baik sebelum proses belajar mengajar berlangsung dan bisa menerapkan pengelolaan kelas yang lebih terorganisir. Guna mengaplikasikan metode-metode dalam pengembangan karakter diperlukan proses manajemen agar metode-metode tersebut dapat diterapkan secara efektif dan efisien melalui fungsi-fungsi manajemen (Ita, 2017); 2) pengetahuan karakter telah dan berkembang lebih pesat dari pada perasaan karakter dan Perbuatan Moral karena pengetahuan tersebut telah didapatkan sebelumnya dari proses pembelajaran mata pelajaran lainnya; 3) Secara keseluruhan perkembangan pengetahuan karakter, perasaan karakter dan Perbuatan Moral mendapat pengaruh yang cukup besar dari pembelajaran metode peer teaching.

\section{SIMPULAN}

Hasil dari penelitian ini mengungkapkan bagaimana perkembangan pengetahuan, perasaan dan Perbuatan Moral dalam pembelajaran matematika. Perkembangan pengetahuan dipengaruhi oleh pemahaman dan penguasaan guru pada karakteristik materi dan pengintegrasian karakter dalam pembelajaran matematika. Perkembangan perasaan moral mendapat pengaruh dari interaksi di dalam kelas antara guru dan siswa dalam pembelajaran matematika dan juga oleh penciptaan kondisi belajar mengajar yang menyenangkan serta kondisi kelas yang nyaman. Perkembangan Perbuatan Moral siswa didorong oleh aktifitas pembelajaran matematika dalam bentuk kelompok dan aktifitas lainnya yang menggiatkan siswa untuk melaksanakan karakter yang terintegrasi di dalam pembelajaran matematika.

\section{UCAPAN TERIMA KASIH}

Ucapan terimakasi kepada Rektor Universitas Tadulako dan Dekan FKIP yang selalu menyemangati penulis dalam hal menerbitkan karya tulis yang relevan dengan bidang keilmuwan.

\section{DAFTAR PUSTAKA}

A. Ahmad, \& Supriyono, W. (2013). Psikologi Belajar. Rineka CIpta.

Amini, M., \& Mariyati, M. (2021). Meningkatkan Karakter Anak Usia Dini melalui Pemberian Penguatan. Jurnal Obsesi: Jurnal Pendidikan Anak Usia Dini, 5(2), 2101-2113. https://doi.org/10.31004/obsesi.v5i2.1128

Ansori, Y. Z. (2021). Strategi Pendidik dalam Menumbuhkan Karakter Jujur pada Anak Usia Dini. Jurnal Obsesi: Jurnal Pendidikan Anak Usia Dini, 6(1), 261-270. https://doi.org/10.31004/obsesi.v6i1.1208

Apriliyanti, F., Hanurawan, F., \& Sobri, A. Y. (2021). Keterlibatan Orang Tua dalam Penerapan Nilai-nilai Luhur Pendidikan Karakter Ki Hadjar Dewantara. Jurnal Obsesi : Jurnal Pendidikan Anak Usia Dini, 6(1), 1-8. https://doi.org/10.31004/obsesi.v6i1.595

Firdaus, C., Mauludyana, B., \& Purwanti, K. (2020). Faktor-Faktor yang Mempengaruhi Motivasi Belajar di SD Negeri Curug Kulon 2 Kabupaten Tangerang. Ilmu Pendidikan Dan Ilmu Sosial, 2(1), 43-52. https:/ / ejournal.stitpn.ac.id/index.php/pensa

Francisca, L., \& Ajisuksmo, C. (2015). Keterkaitan antara Moral Knowing, Perasaan Moral dan Moral Behavior pada Empat Kompetensi Dasar Guru. Jurnal Kependidikan, 45(2), 211-221. https://journal.uny.ac.id/index.php/jk/article/view/7500/6497 
Indrianto, N., \& Sya'diyah, H. (2020). Pengembangan Karakter Mandiri Melalui Pembelajaran Tematik pada Kelas III di Madrasah Ibtidaiyah Negeri 5 Jember. EDUCARE: Journal of Primary Education, 1(2), 137-150. https:/ / doi.org/10.35719/jpe.v1i2.13

Irwansyah, D. (2012). Nilai-Nilai Pengembangan Karakter Dalam Manajemen Kelas Dan Peer Teaching.

Ita, E. (2017). Manajemen Metode Pengembangan Karakter Bagi Anak Usia Dini. Jurnal Edudikara, 2(September), 200-209. https:// doi.org/10.32585/edudikara.v2i3.49

Juwita, R., \& Asep, Munajat, E. (2019). Mengembangkan Sikap Tanggung Jawab Melaksanakan Tugas Sekolah Melalui Metode Bercerita Pada Anak Usia 5-6 Tahun. Utile: Jurnal Kependidikan, V, 144-152.

Kistanti, D. (2019). Analisis Pelaksanaan pendidikan karakter dalam pembelajaran matematika di kelas III Sd Negeri 3 Teunom. ... : Jurnal Ilmiah Pendidikan Guru Sekolah Dasar, 6(1). https://www.ejournal.stkipbbm.ac.id/index.php/pgsd/article/view/410

Lickona, T. (2012). Educating For Characters (1st ed.). Bumi Aksara.

Lie, A. (2008). Cooperative Learning. In Grasindo (6th ed., Vol. 1, Issue 1). Grasindo.

Lyn Longaretti , Sally Godinho, G. P. \& J. W. ( T. U. of M. ). (2002). Rethinking Peer Teaching. Australian Association for Research in Education.

Megawangi, R. (2004). Pendidikan Karakter : Solusi yang tepat untuk membangun Bangsa (p. 90). Indonesia Heritage Foundation.

Muslich, M. (2011). Pendidikan Karakter. In Bumi Aksara (1st ed.). Bumi Aksara.

Pertama, M., Depok, N., \& Palunga, R. (2017). Peran Guru Dalam Pengembangan Karakter Peserta Didik Di Sekolah Menengah Pertama Negeri 2 Depok Sleman. Jurnal Pendidikan Karakter, 7(1), 109-123. https://doi.org/10.21831/jpk.v7i1.20858

Pidarta, M. (2008). Analisis Data Penelitian-penelitian Kualitatif dan Artikel. UNESA University Press.

Pidarta, M. (2009). Wawasan Pendidikan : Mencapai Tujuan Pendidikan Nasional, Pengembangan Afeksi, Dan Budaya Pancasila, Mengurangi Lulusan Menganggur (1st ed.). SIC.

Sabardila, A., Markhamah, M., Arifin, Z., Kusmanto, H., Hidayah, L. N., Kurniasari, A. D., \& Saputro, D. (2021). Menakar Nilai Pendidikan Karakter Acara Televisi pada Anak Usia 6-8 Tahun. Jurnal Obsesi: Jurnal Pendidikan Anak Usia Dini, 6(1), 150-162. https://doi.org/10.31004/obsesi.v6i1.875

Saihu, \& Rohman, B. (2019). Pembentukan Karakter Melalui Model Pendidikan Transformatife Learning Pada Santri Di Pondok Pesantren Nurul Ikhlas Bali. Jurnal Pendidikan Islam, 08(02), 435-452.

Sinaga, R. (2018). Pendidikan Karakter pada Anak Usia Dini. Societas Dei: Jurnal Agama Dan Masyarakat, 5(2), 180. https:// doi.org/10.33550/sd.v5i2.89

Sunarto, M. J. D., \& Sagirani, T. (2014). Inculcation Method of Character Education Based on Personality Types Classification in Realizing Indonesia Golden Generation. International Journal of Evaluation and Research in Education (IJERE), 3(2), 91-98. https://doi.org/10.11591/ijere.v3i2.4199

Sururuddin, M. (2018). Pengembangan Bahan Ajar Tematik Berbasis Character Building Pada Siswa Kelas III Sekolah Dasar. Jurnal Pendidikan Dasar PerKhasa, 4(April), 53-62. https:// doi.org/10.31932/jpdp.v3i1.47

Suyanto, S. (2012). Pendidikan Karakter untuk Anak Usia Dini. Jurnal Pendidikan Anak, 1(1), 6778. https://doi.org/10.21831/jpa.v1i1.2898

Wardani, N. S. (2012). Pengaruh Pendidikan Karakter Pada Pembelajaran Tematik Terhadap Hasil Belajar Siswa Kelas III SD. Seminar Nasional Pengembangan Pendidikan, 509-521.

Wati, F. Y. L. (2015). Pengembangan Pendidikan Karakter Di Sekolah Dasar/Madrasah Ibtidaiyah. Jurnal Mitra PGMI, 1(1), 97-112. https://doi.org/10.46963/mpgmi.v1i1.35 